\title{
Fatal Adenovirus Pneumonia Despite Extracorporeal Life Support Treatments
}

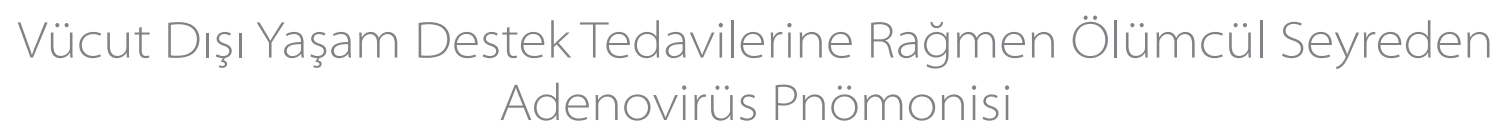

\author{
Osman Yeşilbaş', Esra Şevketoğlu', Hasan Serdar Kıhtır', Mey Talip Petmezci', Ülkem Koçoğlu Barlas', Nihal Akçay', \\ Nevin Hatipoğlu², Sevim Meşe \\ 1 Pediatric Intensive Care Unit, Istanbul Bakirkoy Dr. Sadi Konuk Training Research Hospital, Istanbul, Turkey \\ ${ }^{2}$ Clinic of Pediactric Infectious Diseases, Istanbul Bakirkoy Dr. Sadi Konuk Training Research Hospital, Istanbul, Turkey \\ ${ }^{3}$ Department of Medical Microbiology, Division of Virology and Basic Immunology, Istanbul University School of Istanbul Medicine, Istanbul, Turkey
}

\begin{abstract}
Adenovirus is an important etiological agent of lower respiratory tract infections in all age groups. Its infections are very difficult to distinguish from other viruses and bacterial agents by clinical and laboratory findings. Although adenovirus is rarely causes acute respiratory distress syndrome, it has higher morbidity and mortality compared to other viruses. In this manuscript, an adenovirus infection in a pediatric patient with preliminary diagnosis of bacterial pneumonia by clinical and laboratory findings has been presented. Pneumonia has rapidly progressed to acute respiratory distress syndrome and the patient died despite extracorporeal life support treatments.
\end{abstract}

Keywords: Acute respiratory distress syndrome, adenovirus

\section{Introduction}

The most common cause of respiratory tract infections in children is viruses, and due to the fact that the disease and mortality rates are very high, so fast and accurate diagnosis is very important. Adenovirus is responsible for approximately $5-10 \%$ of all respiratory infections in the pediatric age group. Although it frequently causes upper respiratory tract infec-
Özet

\begin{abstract}
Adenovirüs alt solunum yolu enfeksiyonlarının tüm yaşlarda önemli bir etkenidir. Klinik ve laboratuvar olarak diğer virüs ve bakteriyel enfeksiyonlardan ayrımı oldukça zordur. Akut solunum sıkıntısı sendromuna nadiren sebep olsa da diğer etkenlerle karşılaştırıldığında daha yüksek morbidite ve mortaliteye sahiptir. Bu makalede klinik ve laboratuvar bulguları ile bakteriyel pnömoni ön tanısı alan ve hızlı bir şekilde akut solunum sıkıntısı sendromuna ilerleyen çocuk hastada, vücut dışı destek tedavilerine rağmen ölümcül seyreden adenovirüs enfeksiyonundan bahsedilmiştir.
\end{abstract}

Anahtar Kelimeler: Adenovirüs, akut solunum sıkıntısı sendromu

tions, pneumonia is also an important factor in all ages for lower respiratory tract infections including bronchitis and bronchiolitis. It is quite difficult to distinguish it from other viruses and bacterial infections as clinical and laboratory (1). In the diagnosis, direct methods such as isolation of the virus, detection of antigen or genome can be used. Serologic antibody investigation has negative aspects such as low sensitivity and, in particular, in patients with immunodeficiency, such 
as inadequate antibody response. Although the gold standard diagnostic test is cell culture, it is time consuming and quite laborious. In recent years, polymerase chain reaction (PCR) test has been widely used in the diagnosis of adenovirus, since viral DNA can be detected by rapid molecular methods (2). It is reported that its incidence is higher in children aged between 6 months and 5 years. Although it rarely causes acute respiratory distress syndrome (ARDS), it may be more fatal compared to other factors $(1,2)$. In this article, we have discussed a fatal adenovirus infection in spite of extracorporeal supportive treatments in a pediatric patient who had a pre-diagnosis of bacterial pneumonia and progressed rapidly to ARDS with clinical and laboratory findings.

\section{Case}

A five-year-old male patient was brought to our emergency department with fever and respiratory distress that occurred for four days. As a result of his physical examination and analysis, he was diagnosed with bronchopneumonia and hospitalized in the child service. Oxygen supplementation with a reservoired non-breather mask, intravenous maintenance fluid, ceftriaxone, clarithromycin and nebulous therapy were initiated, and the patient was admitted to the Pediatric Intensive Care Unit (PICU) one day after the respiratory distress increased and his circulation was impaired. It was learned that he was the first child of his parents who were married with first cousins, who had been followed-up for four years and a half because of Dravet's syndrome in pediatric neurology and it was also learned that he had valproat, klobazam and stiripentol treatments for epilepsy. It was stated that he had neuromotor developmental retardation, he can communicate with his parents, only say one word and cannot construct sentence, and also he can crawl and walk with support. Height, body weight and head circumference measurements were within normal range. His general condition was poor, his consciousness was prone to sleeping, and his Glasgow Coma Score (GCS) was 11. The patient's body temperature was $39.1^{\circ} \mathrm{C}$ and blood pressure was 103/63 (mean 78) mmHg (tachypnea: 42/min and tachycardia: $154 / \mathrm{min})$. Pulse oxygen saturation ratio $\left(\mathrm{SpO}_{2}\right)$ was $90 \%$ with the reservoided non-breather mask. Auscultation revealed diffuse inspiratory ral and expiratory wheezing. In his capillary blood gas; $\mathrm{pH}: 7.17, \mathrm{PaCO}_{2}: 72 \mathrm{mmHg}, \mathrm{HCO}_{3}: 19$ $\mathrm{mEq} / \mathrm{L}$, lactate: $5.2 \mathrm{mmol} / \mathrm{L}$ (normal $0.5-2 \mathrm{mmol} / \mathrm{L}$ ). Leukocyte number: $5440 / \mathrm{mm}^{3}$ (lymphocyte $1220 / \mathrm{mm}^{3}$ ), neutrophils: 3900/mm 3), hemoglobin: $11.3 \mathrm{~g} / \mathrm{dL}$, hematocrit: $35.3 \%$, platelet number: $88.000 / \mathrm{mm}^{3}$, C-reactive protein (CRP): $11.5 \mathrm{mg} /$ $\mathrm{dL}$ (normal: 0-0.5 mg/dL), procalcitonin: $1.09 \mathrm{ng} / \mathrm{mL}$ (normal < $0.5 \mathrm{ng} / \mathrm{mL}$ ), aspartate aminotransferase (AST): $101 \mathrm{U} / \mathrm{L}$ (normal $<32 \mathrm{U} / \mathrm{L}$ ), lactate dehydrogenase (LDH): $677 \mathrm{U} / \mathrm{L}$ (normal 135$214 / \mathrm{L}$ ) and albumin: $2.9 \mathrm{~g} / \mathrm{dL}$. Other serum biochemistry, elec- trolytes and coagulation tests of the patient were normal. The patient, whose chest X-Ray revealed bilateral paracardiac infiltration (Figure 1A), was supported with noninvasive mechanical ventilator (NIMV) with ketamine infusion. Teicoplanin was added to the antibiotic treatment he was taking. Intraarticular magnesium sulfate and nebulized salbutamol treatments were performed and echocardiography of the patient was normal. As the capillary filling time was long (4 s), the lactate was high, he was dehydrated and tachycardic, saline loading was performed twice at $20 \mathrm{~mL} / \mathrm{kg}$. He was intubated after six hours because his respiratory failure did not regress despite of drug treatments and NIMV and he was connected to mechanical ventilator with midazolam, ketamine and rocuronium infusion. After the intubation process, chest radiography (Figure $1 \mathrm{~B}$ ) and oxygen saturation rate [mean airway pressure (MAP) $\mathrm{X}$ ratio of inhaled oxygen $\left(\mathrm{FiO}_{2}\right) \times 100 / \mathrm{SpO}_{2}$ ] were compatible with ARDS. Moderate hypercapnia and moderate hypoxemia were allowed in blood gas by targeting lung protective mechanical ventilation. $\mathrm{SpO}_{2}$ was $80-82 \%$ despite high ventilator pressures on the third day of his admission to intensive care unit. In Arterial blood gas; $\mathrm{pH}: 7.34, \mathrm{PaO}_{2}: 29.3 \mathrm{mmHg}$, $\mathrm{PaCO}_{2}: 51 \mathrm{mmHg}, \mathrm{HCO}_{3}: 25.3 \mathrm{mEq} / \mathrm{L}$, lactate: $1.6 \mathrm{mmol} / \mathrm{L}$. For the patient whose oxygenation rate was $50\left(\mathrm{MAP} \times \mathrm{FiO}_{2} \times 100 /\right.$ $\mathrm{PaO}_{2}$ ), because he did not have sufficient oxygenation, it was decided to perform extracorporeal membrane oxygenation (ECMO) on the third day of PICU admission. Then, the patient's $\mathrm{SpO}_{2}$ value was increased from $80 \%$ to $85 \%$ although without decreasing the ventilator settings. ECMO blood flow rate was adjusted based on pulse oxygen saturation and the ECMO gas flow was adjusted based on $\mathrm{FiO}_{2}, \mathrm{PaCO}_{2}$ as dynamically. Due to the absence of improvement on chest radiographs (Figure 1C,1D) and oxygenation, and edemas despite limited fluid therapy, continuous renal replacement therapy (SRRT) was started on the fifth day of PICU hospitalization. As procalcitonin and CRP levels increased slightly, ceftriaxone treatment was replaced with meropenem, although there was no reproduction in their culture. Because in his direct dominance, hyperbilirubinemia develops, inotropic is needed and platelet count is less than $100.000 / \mathrm{mm}^{3}$, it was considered thrombocytopenia-related multiorgan failure (TMOF) and it was decided to perform daily plasma exchange with fresh frozen plasma. On the sixth day of PADD, despite the ECMO increased blood flow rate and the high pressures in the mechanical ventilator, $\mathrm{SpO}_{2}$ ranged $80-82 \%$. A bilateral chest tube was placed on the seventh day of PICU admission pursuant to the detection of bilateral pleural effusion radiologically (chest X-Ray + thoracic ultrasonography) (Figure $1 \mathrm{H}$ ). The tuberculosis analysis of exudate pleural fluid was negative. Immunoglobulin and lymphocyte subgroup levels conducted for immune deficiency of the patient were normal. On the ninth day of hospitalization, 
the patient could not have any improvement in ARDS findings despite advanced extra-body supportive treatments and his $\mathrm{SpO}_{2}$ level decreased and bradycardia developed. Although effective heart-lung resuscitation was started, the patient had no cardiac response and died shortly after the operation. Pneumomediastinum developed on the chest radiography immediately before the onset of heart-lung resuscitation despite the bilateral chest tube (Figure 11). There was no growth in the patient's blood, tracheal aspirate, pleural fluid and urine samples during his hospitalizaiton period. Influenza virus type $A$ and $B$, parainfluenza virus type $1-4$, respiratory syncytial virus (A / B), rhinovirus, human bocavirus, metapneumovirus, coronavirus (229E, NL63, HKU, OC43), paraecovirus, enterovirus, adenovirus and Mycoplasma pneumoniae were investigated with multiplex real-time rtPCR method in RotorGene 3000 (QIAGEN, Germany) device by using FTD ${ }^{\circledR}$ respiratory pathogens 21 (Fast-Tract Diagnostics, Luxembourg) kit in the nasopharyngeal swab sample obtained with the Virocult (Medical Wire Equipment CO, UK) swab for a viral etiological examination. This study was conducted in Istanbul University, Istanbul Medical Faculty Virology and Immunology Department. According to the late results obtained due to inter-hospital referral chain procedures, all factors except adenovirus were negative.

\section{Discussion}

The most prominent features of lower respiratory tract infections secondary to adenovirus in childhood are high and long duration fever, radiological findings imitating bacterial infection, and high levels of acute phase markers such as CRP and neutrophil counts. Therefore, in order to prevent unnecessary use of antibiotics in these patients, the use of rapid diagnostic methods (such as nasal swab PCR) including other viral agents is extremely important (1). Interestingly, our patient also had high levels of procalcitonin, which was associated with neutrophilia and CRP elevation and was used to differentiate between bacterial and viral infections. Kim et al. detected high procalcitonin levels in five patients (71\%) according to the study they conducted on the seven adults with severe pneumonia secondary to adenovirusn and without immunedeficiency, similar to our study (3).

Although ARDS due to adenovirus is less common in children, it is reported to be more frequent and to have higher mortality in patients with immunodeficiency compared to other viral agents (4). Jonnalagadda et al. reported that the third most common cause after RSV and hMPV was adenovirus as an active microorganism in 406 pediatric patients between two and 59 months of age with severe pneumonia (5). Meyer et al. detected that the third most common cause was adenovirus in 12 patients of 127 children with viral pneumonia requiring ECMO between 1988 and 1994 (6). These children who received ECMO support for viral pneumonia secondary to adenovirus were found to be the worst prognosis group with $75 \%$ mortality (6). Prodhan et al. studied the children with adenovirus pneumonia requiring ECMO by using the records of extracorporel life support organization between 1998 and 2009 (4). While 38\% (62/163) of all children survived and were discharged from the hospital, only $11 \%(7 / 55)$ of 55 newborns ( $<31$ days) survived. In this study, neonatal period, use of high-speed ossilatory ventilator (HFOV) before ECMO, low $\mathrm{pH}-\mathrm{SpO}_{2}-\mathrm{PaO}_{2^{\prime}}$, high $\mathrm{CO}_{2}$ and sepsis were associated with high mortality. Oxygenation rate with $\mathrm{PO}_{2} / \mathrm{FiO}_{2}$ was not associated with mortality (4). Furthermore; pleural effusion, which requires hypotension, leukopenia, thrombocytopenia, elevated LDH-AST, and drainage, is shown as indicator of poor prognosis in adenovirus-induced pneumonia and ARDS cases (7). All of these poor prognosis indicators were observed during the hospitalization of our patient who had no immune deficiency and before ECMO, HFOV was not applied to.

According to the current study and case reports in the literature, ARDS therapy secondary to adenovirus includes respiratory support, limited fluid, antiviral drugs, HFOV, ECMO and SRRT $(3,4,8,9)$. Although we started ECMO treatment on the third day of hospitalization, we did not reduce the ventilator's values in accordance with the goal of restraining lungs and preventing the toxic effects of oxygen.

It has been showed that the cidofovir, which is a broad-spectrum antiviral drug and functions by pressuring the DNA polymerase, is experimentally effective against all types of adenovirus. Currently, the efficacy of this drug, which is approved for the treatment of cytomegalovirus retinitis in the patients with Acquired Immune Deficiency Syndrome (AIDS), has not been proven against adenovirus in randomized controlled studies by FDA (Food and Drug Administration). However, in the literature, there are case series and small studies indicating that it is effective in patients with ARDS secondary to adenovirus $(3,8,9)$. Kim et al. stated that they had a successful result with the early onset ofcidofovir in seven adult patients with severe pneumonia secondary to adenovirus and with no immunodeficiency (3). Ha et al. successfully treated two adult patients with ARDS caused by adenovirus with the early onset of ECMO, SRRT and cidofovir (8). They suggested that fluid overload and electrolyte imbalance could be prevented by continuous renal replacement therapy and immunomodulation could also be achieved (8). We started SRRT on the fifth day of PICU admission of the patient who undergone limited fluid treatment because the edemas developed. Although we draw daily fluid in balance and edema were regressed, no significant improvement was observed in oxygenation. Plasmapheresis treatment 


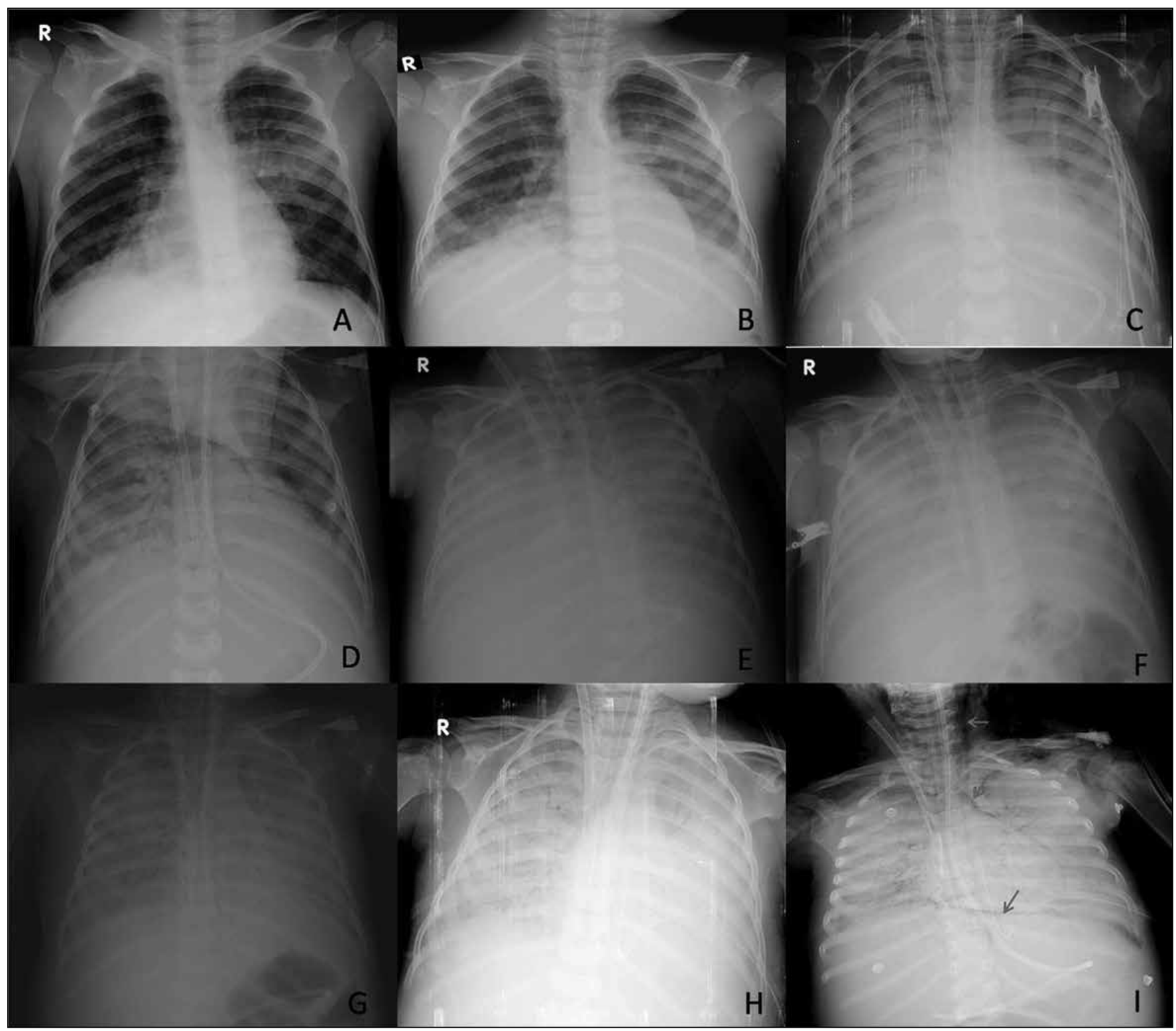

Figure 1. Daily chest radiographs of the patient in the pediatric intensive care unit. A. The first chest radiography in a pediatric intensive care unit. B. Second day. C. Third day (First ECMO day). D. Fourth day (Second ECMO day). E. Fifth day (Third ECMO day). F. Sixth day (Fourth ECMO day). G. Seventh day (Fifth ECMO day). H. Eighth day (Sixth ECMO day). I. Ninth day (Seventh ECMO day). The red arrows in the image indicate subcutaneous emphysema in the neck region and air around the heart compatible with pneumomediastum. ECMO: Extracorporeal membrane oxygenation.

was also applied because TAMOF with high rate of morbidity and mortality developed and reported to be beneficial in the studies $(10,11)$. Because the nasal swab PCR result was sent to another hospital with the delivery chain and resulted late, we did not have the possibility to start treatment of cidofovir early. In the case of our patient who had fatal follow-up, we think that if we had started earlier, the cidofovir would have been beneficial with other high level extracorporeal support treatments when we considered the literature data.
As a result; adenovirus can imitate bacterial infections by clinical, radiological and laboratory findings and may cause fatal ARDS. For the diagnosis of adenovirus, that rapid resulting tests such as PCR should be widespread in each hospital will prevent the use of unnecessary antibiotics. We think that, as a result of rapid diagnosis of patients with severe course of pneumonia and ARDS, morbidity and mortality rates may be reduced by starting early cidofovir and extracorporeal support therapies. 
Informed Consent: Written patient consent was obtained the patient's family.

Peer-review: Externally peer-reviewed.

Author Contributions: Concept - OY, EŞ; Design - OY, HSK; Check - EŞ, $\mathrm{NH}$; Data Collection and/or Processing - MTP, NA, ÜKB, SM; Literature Review - OY, HSK; Writing - OY; Critical Review - EŞ.

Conflict of Interest: The authors have not reported a conflict of interest.

Financial Disclosure: There is no financial support in this study

\section{References}

1. Biçer $S$, Küçük $O$, Giray $T$, et al. Evaluation of clinical and laboratory findings of pediatric patients with adenovirus-associated respiratory tract infections. Mikrobiyol Bul 2013;47:295-304.

2. Sağlık I, Mutlu D, Ongüt $G$, et al. Investigation of adenoviruses in children with lower respiratory tract infections. Mikrobiyol Bul 2013;47:282-94.

3. Kim SJ, Kim K, Park SB, Hong DJ, Jhun BW. Outcomes of early administration of cidofovir in non-immunocompromised patients with severe adenovirus pneumonia. PLoS One 2015;10:e0122642.

4. Prodhan P, Bhutta AT, Gossett JM, et al. Extracorporeal membrane oxygenation support among children with adenovirus infection: a review of the Extracorporeal Life Support Organization registry. ASAIO J 2014;60:49-56.
5. Jonnalagadda S, Rodríguez O, Estrella B, Sabin LL, Sempértegui F, Hamer $\mathrm{DH}$. Etiology of severe pneumonia in Ecuadorian children. PLoS One 2017;12:e0171687.

6. MeyerTA, WarnerBW. Extracorporeal life support for the treatment of viral pneumonia: collective experience from the ELSO registry. Extracorporeal Life Support Organization. J Pediatr Surg 1997;32:232-6.

7. Shen CF, Wang SM, Ho TS, Liu CC. Clinical features of community acquired adenovirus pneumonia during the 2011 community outbreak in Southern Taiwan: role of host immune response. BMC Infect Dis 2017;17:196.

8. Ha SO, Kim HS, Park S, et al. Severe ARDS caused by adenovirus: early initiation of ECMO plus continuous renal replacement therapy. Springerplus 2016;5:1909.

9. Ganapathi L, Arnold A, Jones S, et al. Use of cidofovir in pediatric patients with adenovirus infection. F1000Res 2016;5:758.

10. Sevketoglu E, Yildizdas $D$, Horoz $O O$, et al. Use of therapeutic plasma exchange in children with thrombocytopenia-associated multiple organ failure in the Turkish thrombocytopenia-associated multiple organ failure network. Pediatr Crit Care Med 2014;15:e354-9.

11. Nguyen TC, Carcillo JA. Therapeutic plasma exchange as a strategy to reverse multiple organ dysfunction syndrome in patients receiving extracorporeal life support. Pediatr Crit Care Med 2015;16:383-5. 